F110

\title{
作業環境としての産婦人科外来内診ブースに 必要なスペースについての検討
}

齊藤 英子 $^{1}$

${ }^{1}$ 東京電力病院 産婦人科

産婦人科における外来診療の特徵は、一般診療中に多くの検查を内診台で行なうこと、検査は主に坐位での 上肢作業であること、プライバシー保護のため、壁で仕切られた空間に機器が配置されていること、の 3 点 である。このような条件のもとに行なわれる外来業務を通じて、肩凝り、上肢痛などを訴えるものが見られ ることから、内診ブース内のレイアウトを、作業環境の観点から検討した。検討項目は診察に必要な主たる 機器の、実際の使用状態でのサイズ、および配置によって必要となる作業スペースである。

【機器のサイズ（横幅 $\mathrm{cm} \quad \mathrm{x} \quad$ 奥行き $\mathrm{cm}$ )】

(1)内診台：非回転式 $95 \times 150 、 95 \times 147$ 、回転式 $100 \times 130$

(2)照明付き診療ユニット $65 \times 60 、 85 \times 55 、 47 \times 40$

(3)経㓐超音波装置 $50 \times 50 、 50 \times 68$

(4)コルポスコープ $75 \times 60$ (ただし横幅の、壁からの必要距離は $50 \mathrm{~cm})$

(5)ヒステロファイバースコープ・セット $50 \times 65$

上記に加え、作業者として、医師が座る椅子（直径 $55 \mathrm{c} \mathrm{m}$ ) が必要である。

[使用機器の組み合わせ]上記機器のうち、1つのブース内で使用されるものは、(1)(2)+(3)が最小セットで あることが多く、他に(1)(2)+(4)、(1)(2)+(5)あるいは、(1)(2)+(3)+(4)、(1)(2)+(3)+(5)などの組み合わせも 見られた。

【最小セットに必要なスペースについての検討】（1)(2)+(3)で、作業者が座した状態で作業するために必要な 左右の横幅を検討する。作業者は(1)の正面に座し、(2)は右に、(3)は左にそれぞれ横向きに置かれることが多

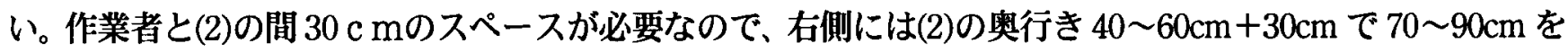
要する。一方、左側は超音波の奥行き十操作スペースとして $50 \sim 68 \mathrm{~cm}+20 \mathrm{~cm}$ で、 $70 \sim 88 \mathrm{~cm}$ を要する。こ れらに椅子のスペース $55 \mathrm{c} \mathrm{m}$ を加えると $195 \mathrm{~cm} \sim 243 \mathrm{~cm}$ が必要となる。内診台は、使用する経㓐超音波装置 の大きさをもとに、左側の壁から内診台の左端まで 70 88cm の距離をもって配置したい。これ以下の場合、 作業者は内診台の正面に座れないことがある。また、看護師が介助につく場合には、作業者の右側、(2)との 間にさらに $30 \mathrm{~cm}$ ほどのスペースが必要である。内診台が非回転式の場合、内診ブースの横幅は上記程度で も作業可能であるが、回転式の場合はその円軌道に物品を置くことができないこと、奥行き $130 \mathrm{c} \mathrm{m}$ に下腿 の長さを加える必要があることから、さらに $50 \mathrm{~cm}$ ほどの横幅が必要となる。

【他セットに必要なスペースについての検討】実際の測定結果から、機器の奥行きは 70cm 以内のものがほと

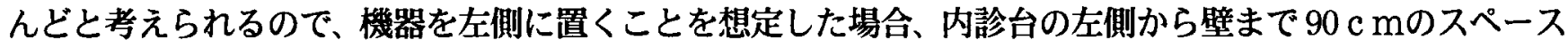
があれば、産婦人科診㙩で必要な機器はほほ配置可能と考えられる。

[考察] 従来、内診ブースは内診台のみ、内診台と診療ユニットのみが配されるのみで、あまり横幅を必要と せず、 $180 \mathrm{~cm}$ でも診㙩可能であった。しかしながら、さまざまな診療機器の登場して来たことにより、従来 のものでは手狭になり、作業者に無理な姿勢を強いている場合がある。また、受診者の快適性を配慮し、回 転式内診台も普及しているが、装置を優先するために、作業に必要なスペースが鸼牲になっている場合もあ

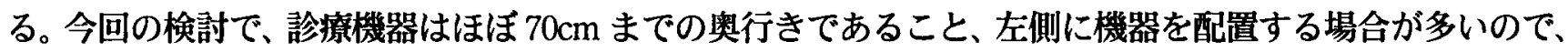
特に左側の作業スペースを十分確保できるよう内診台を含め、配置を検討することが旰要であることが判明 した。 